\title{
Implementasi E-Arsip Pada Program Studi Teknik Informatika
}

\author{
Muhammad Dedi Irawan ${ }^{1}$, Selli Aprilla Simargolang ${ }^{2}$ \\ ${ }^{1,2}$ Teknik informatika, universitas asahan \\ Jl Jend.Ahmad Yani, Kisaran, Sumatera Utara 21216, Indonesia \\ $1_{\text {temansejati.dediegmail.com, }{ }^{2} \text { sellygolang@gmail.com }}$
}

\begin{abstract}
Abstrak - Pembuatan Implementasi E-Arsip pada Program Studi Teknik Informatika ini diupayakan untuk kesempurnaan dalam penyelenggaraan kearsipan yang selama ini belum bersifat terpadu, dan seringkali pengelolaan dokumen-dokumen masih dilakukan secara manual. Sehingga membuat pekerjaan menjadi tidak efektif dan efisien ketika dihadapkan pada kebutuhan informasi yang cepat. Metode pengumpulan data yang digunakan adalah melalui observasi dan studi pustaka. Berdasarkan tinjauan teori, analisis serta implementasi pemograman yang digunakan dengan bahasa pemgoraman PHP dengan editor Notepad ++ dan database menggunakan XAMPP, sehingga menghasilkan pemograman e-arsip yang berbasiskan web, yang dapat digunakan secara langsung pada Program Studi Teknik Informatika yang dapat membantu proses penyelenggara kearsipan yang sesuai dengan prinsip. Sehingga nantinya dalam proses pencarian data dan informasi arsip menjadi lebih mudah, dan lebih akurat.
\end{abstract}

Kata Kunci - E-Arsip, Implementasi, Web

\section{PENDAHULUAN}

Terdapat beberapa instansi-instansi yang belum mengikuti perkembangan dalam pengeolaan arsip. Dalam pengelolaannya instasi-intasi tersebut tidak terlalu memperhatikan pengelolaan arsip khususnya arsip berbasis elektronik. Dan hasil dari sebagian besar masih berupa arsip jenis kertas. Hal ini mengakibatkan pada banyaknya arsip kertas. Sehingga menimbulkan berbagai masalah terkait dengan tempat penyimpanan, biaya pemeliharaan, tenaga pengelola, fasilitas, ataupun faktor lain yang bisa menyebabkan kerusakan arsip.

Oleh sebab itu pemanfaatan teknologi informasi dan komunikasi dalam berupa media komputer juga menjadi alasan mengapa arsip harus dikelola secara elektronik. Dengan adanya media elektronik seperti komputer dan aplikasi-aplikasi berbasiswa desktop maupun web dapat membantu proses pengelolaan dan pengurusan arsip akan menjadi lebih mudah dan tidak akan memakan waktu lama. Pemanfaatan komputer dapat menjadikan arsip konvensional menjadi digital atau juga dapat menciptakan arsip elektronik. Penggunaan media elektronik dalam pengelolaan arsip inilah yang sering disebut sebagai Sistem Pengarsipan Elektronik (Electronic Filing System) yang berbasiskan pada penggunaan komputer.

\section{LANDASAN TEORI}

\section{A. Pengertian Implementasi}

Menurut Rimaru (dalam Rita Prima Bendriyanti dan Leni Natalia Zulita, 2012), implementasi merupakan suatu proses mendapatkan suatu hasil yang sesuai dengan tujuan atau sasaran kebijakan itu sendiri. Dimana pelaksana kebijakan melakukan suatu aktivitas atau kegiatan.

\section{B. Pengertian Arsip}

Menurut Normah (2017), arsip merupakan hal yang paling utama dan mendasar yang harus diperhatikan dalam segala jenis kegiatan administrasi, manajemen dalam suatu organisasi dikarenakan arsip merupakan data informasi yang tersimpan mengenai segala hal yang kita kerjakan dalam rutinitas harian. Dalam administrasi dan manajemen arsip berperan sangat vital sebagai bahan untuk perencanaan, bahan pengawasan dan pelaporan, bahan utama pengambilan keputusan dalam suatu organisasi dan tanpa arsip tidak mungkin suatu organisasi dapat beroperasi dengan tertib, teratur dan lancar. Pengelolaan arsip yang tidak teroganisir dengan baik akan menyulitkan kita pada saat kita memerlukan kembali atau memanfaatkan kembali data tersebut, terutama dalam pencarian datanya, terlebih lagi jika kita sedang membutuhkan data tersebut dalam waktu yang tergesa-gesa.

\section{Tujuan Penyimpanan Arsip}

Menurut Haryadi (dalam Fauziah Latif dan Aditya Wirangga Pratama, 2015), tujuan penyimpanan arsip adalah sebagai pusat ingatan dan informasi jika berkas diperlukan sebagai keterangan, memberi data kepada pegawai yang memerlukan data mengenai hasil-hasil kegiatan dan pekerjaan pada masa lampau, memberikan keterangan vital, sesuai dengan ketentuan perundang-undangan.

\section{Pengertian E-Arsip}

Menurut publikasi kominfo (dalam Rita Prima Bendriyanti dan Leni Natalia Zulita, 2012), e-arsip adalah sebuah sistem kearsipan secara elektronis yang dapat digunakan oleh staf atau pegawai instansi pemerintahan sebagai suatu alat yang berguna dalam memantau dan mengelola hal-hal yang berkaitan dengan sistem kearsipan baik berbentuk berkas, folder, audio, visual.

\section{E. Manfaat Manajemen Arsip Elektronik}

Menurut Fauziah Latif dan Aditya Wirangga Pratama (2015), beberapa manfaat penggunaan sistem pengelolaan secara elektonik yang mendorong sebagian besar organisasi untuk mengimplementasikan manajemen arsip elektronik diantaranya adalah:

1. Cepat ditemukan dokumen tanpa meninggalkan meja kerja dan memungkinkan pemanfaatan arsip. 
2. Pengindeksan yang fleksibel dan Pencarian dengan mencari file berdasarkan kata kunci maupun nama file dan ditemukan nya dalam bentuk full text dokumen secara full-text,

3. Kita hanya dapat melihat dilayar monitor atau print-nya tanpa dapat mengubahnya. Sehingga kecil kemungkinan file akan hilang.

4. Resiko rusak nya dokumen kertas atau buram karena usia dapat diminimalisir karena tersimpan secara digital.

5. Lebih accountable menuju good governance karena manajemen pengawasan yang lebih mudah, cepat.

6. Mudah memback-up data kedalam media penyimpanan yang compatible dalam melakukan recovery data.

\section{F. Kelebihan dan Kekurangan Pengelolaan Arsip} Elektronik

Menurut Machsun Rifauddin (2016), adapun diantara kelebihan pengelolaan arsip elektonik antara lain:

1. Proses pencarian dokumen lebih cepat, tanpa harus meninggalkan meja kerja.

2. Arsip elektronik hanya dapat dilihat di layar monitor atau dicetak tanpa dapat mengubahnya. Sehingga kemungkinan file akan hilang sangat kecil.

3. Kenggunakan media penyimpanan elektonik berbasis digital. Sehingga menghemat tempat penyimpanan dan dapat meminimalisir kerusakan dokumen.

4. Dengan memanfaatkan teknologi internet. Berbagi dokumen dapat dilakukan secara mudah.

5. Orang lain yang tidak mempunyai otoritas tidak dapat untuk mengaksesnya. Karena Keamanan terjaga, dengan protect atau pasword sesuai keinginan pengelolanya, maka Mudah dalam melakukan recovery data, dengan cara memback-up data kedalam media penyimapanan yang compatible.

Sedangkan kekurangan pengelolaan arsip elektronik antara lain:

1. Dibutukan SDM yang berkompeten dibidang kearsipan dan teknologi Informasi.

2. Kemungkinan kerusakan file dapat terjadi setiap saat, misalnya terhapusnya file secara permanen karena tidak sengaja karena kesalahan SDM nya dan server terserang oleh virus.

3. Apabila proteksi tidak kuat dapat terjadi kemungkinan untuk di manipulasinya file.

4. Teknologi informasi baru berkembang sangat pesat. Sehingga terkadang media penyimpanan file tidak comfortable/support .

\section{G. Pengertian Implementasi E-Arsip}

Menurut Wallace (dalam Rita Prima Bendriyanti dan Leni Natalia Zulita, 2012), sistem kearsipan adalah untuk kepentingan operasional dengan asas bahwa hanya informasi yang tepat digunakan oleh orang yang tepat dan untuk kepentingan tepat pada waktu yang tepat dengan biaya serendah mungkin dengan rangkaian subsistem dalam manajemen kearsipan yang bekerja sama untuk mencapai tujuan agar arsip tertata dalam unit-unit informasi siap pakai.

Sistem kearsipan harus bisa mencakup semua subsistem dalam manajemen kearsipan. Manajemen kearsipan dimaknai sebagai pelaksanaan fungsi-fungsi manajeman di dalam rangka mengelola keseluruhan daur hidup arsip. Daur hidup arsip mencakup proses penciptaan, pendistribusian, penggunaan, penyimpanan arsip aktif, pemindahan arsip, penyimpanan arsip inaktif, pemusnahan, dan penyimpanan arsip permanen.

Pengertian implementasi e-arsip dapat suatu proses yang dinamis dalam melakukan kegiatan kearsipan untuk memantau dan mengelola hal-hal yang berkaitan dengan sistem kearsipan.

\section{H. Pengertian Web}

Menurut M.Rudyanto Arief (dalam Medi Suhartanto, 2012), web adalah salah satu aplikasi yang berisikan dokumen-dokumen multimedia didalamnya yang menggunakan protokol HTTP (hyper text transfer protocol) dan dalam mengunakan perangkat lunak yang disebut browser.. Browser (perambah) adalah aplikasi yang mampu menjalankan dokumendokumen web dengan cara diterjemahkan. Prosesnya dilakukan oleh komponen yang terdapat didalam aplikasi browser yang biasa disebut web engine. Semua dokumen web ditampilkan dengan cara diterjemahkan. Beberapa jenis browser yang populer saat ini di antaranya : Internet Exspoler yang diperoduksi oleh Microsoft, Mozila Firefox, Opera dan Safari yang diperoduksi oleh Aplle

\section{Pengertian PHP (Hypertext Preprocessor)}

PHP adalah bahasa pemprograman script server-side yang didesain untuk mengembangkan web. Disebut bahasa pemprograman server side karena PHP diproses pada komputer server. PHP (Hypertext Preprocessor) adalah bahasa script yang dapat dipakai untuk membuat program situs web dinamis. Hal ini berbeda dibandingkan dengan bahasa pemrograman client-side seperti JavaScript yang diproses pada web browser (client). (Madcoms. 2016:2)

\section{J. Pengertian Database}

Menurut Cosmas Eko Suharyanto, Dkk (2017), basis data atau database adalah kumpulan data terstruktur. Sehingga dapat menambahkan, mengakses, dan memproses data yang tersimpan dalam database komputer, untuk membuat database dibutuhkan sistem manajemen basis data (database management system). 


\section{K. Pengertian MySQL}

Menurut Sutaji (dalam Sri Haryanti dan Tri Irianto, 2011), MySQL adalah sistem managemen database SQL yang bersifat Open Source dan paling populer saat ini. Database ini dibuat untuk keperluan sistem database yang cepat, handal dan mudah digunakan. Sistem database MySQL mendukung beberapa fitur seperti multithreaded, multi-user dan SQL database managenen sistem (DBMS).. (Madcoms. 2016:2).

L. Pemodelan Berorientasi Objek Menggunakan Unified Modeling Language (UML)

Menurut Windu Gata (dalam Ade Hendini, 2016), UML merupakan metodologi dalam mengembangkan sistem berorientasi objek dan juga merupakan alat untuk mendukung pengembangan sistem. UML juga merupakan Bahasa spesifikasi standar yang dipergunakan untuk mendokumentasikan, menspesifikasikan dan membanngun perangkat lunak. Alat bantu yang digunakan dalam perancangan berorientasi objek berbasiskan UML adalah sebagai berikut:

1. Use Case Diagram

Use case digunakan untuk mengetahui fungsi apa saja yang ada di dalam sistem informasi dan siapa saja yang berhak menggunakan fungsifungsi tersebut. Use case diagram merupakan pemodelan untuk kelakuan (behavior) sistem informasi yang akan dibuat.

2. Diagram Aktivitas (Activity Diagram)

Activity Diagram menggambarkan workflow (aliran kerja) atau aktivitas dari sebuah sistem atau proses bisnis.

3. Diagram Urutan (Sequence Diagram)

Sequence Diagram menggambarkan kelakuan objek pada use case dengan mendeskripsikan waktu hidup objek dan pesan yang dikirimkan dan diterima antar objek.

4. Diagram Kelas (Class Diagram)

Diagram Kelas (Class Diagram) merupakan hubungan antar kelas dan penjelasan detail tiaptiap kelas di dalam model desain dari suatu sistem, juga memperlihatkan aturan-aturan dan tanggung jawab entitas yang menentukan perilaku sistem.

\section{Package Diagram}

Package Diagram (diagram paket) adalah sekelompok elemen-elemen model.sebuah paket dapat berisi elemen-elemen model yang berlainan, termasuk untuk paket-paket untuk menciptakan/ menggambarkan sifat hiraki. Sebuah paket diberi nama yang menggambarkan isinya
6. Collaboration Diagram

Diagram ini bersifat dinamis. Diagram kolaborasi adalah diagram interaksi yang menekankan organisasi struktural dari objek-objek yang menerima serta mengirim pesan (message).

7. Diagram Komponen (Component Diagram)

Component diagram menggambarkan struktur fisik dari kode, pemetaan pandangan logis dari kelas proyek untuk kode aktual di mana logika ini dilaksanakan.

\section{Deployment Diagram}

Deployment diagram memberikan gambaran dari arsitektur fisik perangkat lunak, perangkat keras, dan artefak dari sistem. Deployment diagram dapat dianggap sebagai ujung spektrum dari kasus penggunaan, menggambarkan bentuk fisik dari sistem yang bertentangan dengan gambar konseptual dari pengguna dan perangkat berinteraksi dengan sistem.

\section{METODE PENELITIAN}

\section{A. Metodologi Penelitian}

Metode penelitian ini adalah suatu cara yang digunakan untuk mendapatkan informasi yang dibutuhkan dalam menyusun penelitian. Dalam penyusunan ini, peneliti menggunakan beberapa metode untuk mendapatkan informasi yang dibutuhkan.

\section{B. Kerangka Kerja Penelitian}

Adapun kerangka kerja yang peneliti lakukan dapat dilihat dari gambar di bawah ini:

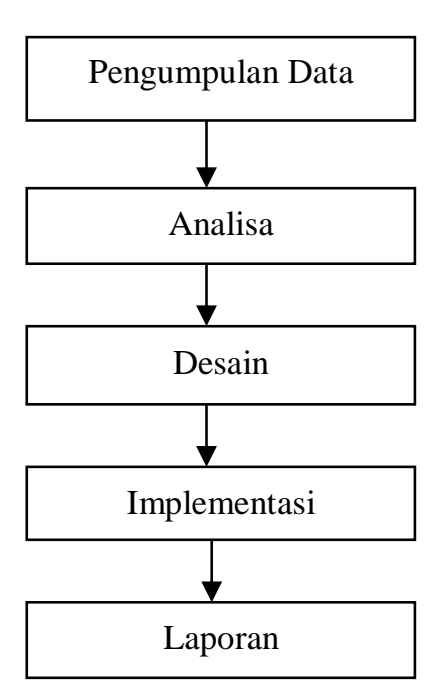

Gambar 1 Kerangka Kerja 


\section{Objek Penelitian}

Adapun objek penelitian yang peneliti lakukan adalah Arsip Program Studi Teknik Informatika Universitas Asahan.

\section{Operasional Variabel}

Operasional variabel dalam penelitian ini adalah bagaimana mengelola dokumen dengan menggunakan bahasa pemograman berbasis web, variabel yang digunakan adalah sebagai berikut :

1. Surat Masuk.

2. Surat Keluar.

\section{E. Metode Analisa Sistem}

Dalam penelitian ini, peneliti akan menganalisa sistem yang akan dirancang menggunakan UML (Unified Modeling Language), yang menggambarkan aliran sistem secara menyeluruh mulai dari user yang terkait sampai kepada aktivitas dan input yang dilakukan dalam sistem.

Pada tahap ini dibuat pemodelan kebutuhan sistem informasi dengan menggunakan Use Case diagram, Activity Diagram, Sequence Diagram dan Class Diagram, package Diagram, Collaboration Diagram, Component Diagram, dan Deployment Diagram.

\section{IV.ANALISIS DAN IMPLEMENTASI}

\section{A. Analisa Sistem Berjalan}

Sistem yang sebelumnya yang berjalan masih menggunakan proses manual yaitu dengan pendataan pada microsoft excel, office dan buku agenda manual dalam mendata surat masuk dan keluar atau arsip lainnya. Hal ini tentu sangat rumit dan tidak efektif dalam mengelola arsip. Maka perlu menggunakan sistem arsip berbasis web yang dapat membantu dalam proses manajemen arsip agar dapat membantu program studi teknik informatika dalam mengelola surat dengan baik, cepat dan akurat.

\section{B. Analisis Data}

Analisis data adalah berupa data apa saja yang dapat diolah dalam sistem arsip. Dalam sistem arsip data yang dapat diolah adalah data surat masuk, surat keluar, data KHS atau KHS mahasiswa serta dokumen-dokumen yang lain yang sipatnya penting. Semua data tersebut dapat diarsipkan dengan mudah dan lebih efektif serta efesien.

\section{Perancangan Sistem}

1. Use Case Diagram

Perancangan model dengan use case menggambarkan perilaku sistem yang dibuat. Dalam sistem pendukung keputusan yang peneliti buat, terdapat 2 aktor yaitu kaprodi dan sekretaris.

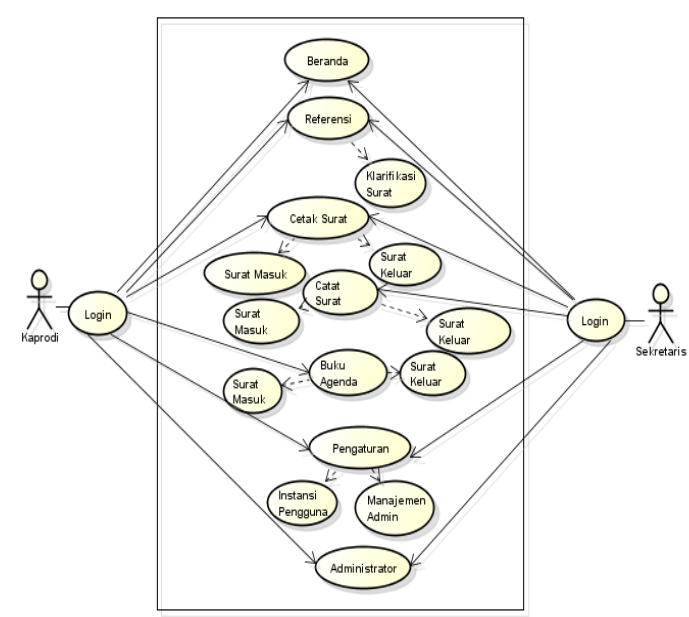

Gambar 2 Use Case Diagram

\section{Activity Diagram}

Perancangan Activity Diagram admin dan umum mengambarkan bagaimana alur aktivitas yang terjadi antara kaprodi dan sekretaris untuk melakukan aktivitas dalam proses akses informasi yang ada pada sistem, Adapun gambarnya seperti berikut:

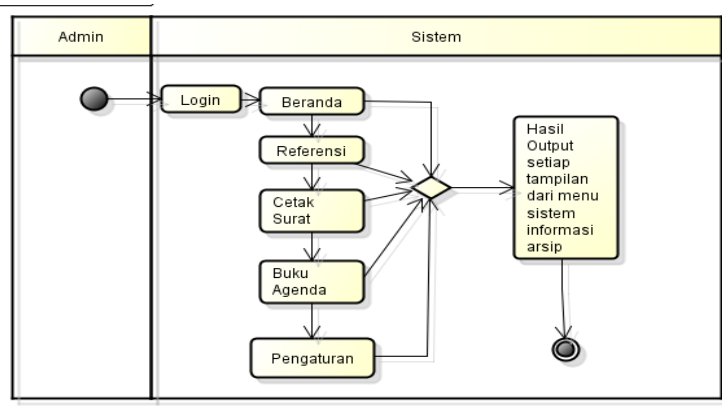

Gambar 3 Activity Diagram Kaprodi

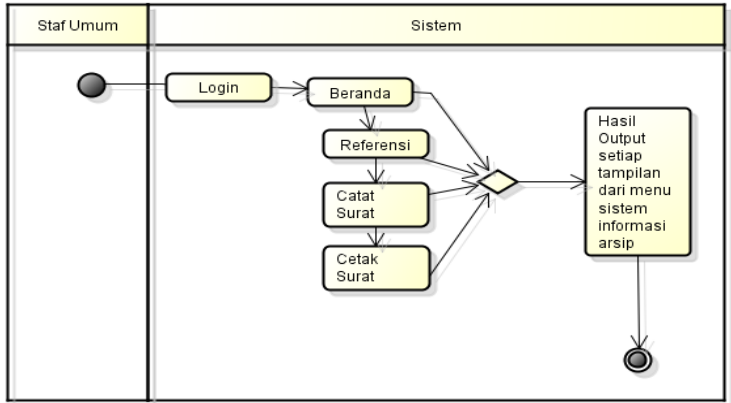

Gambar 4 Activity Diagram Sekretaris

\section{Class Diagram}

Dari perancangan diagram akan dapat diketahui bagaimana hubungan antara tabel didalam database dan proses input apa saja yang ada didalamnya. Untuk gambar dapat dilihat dibawah ini. 


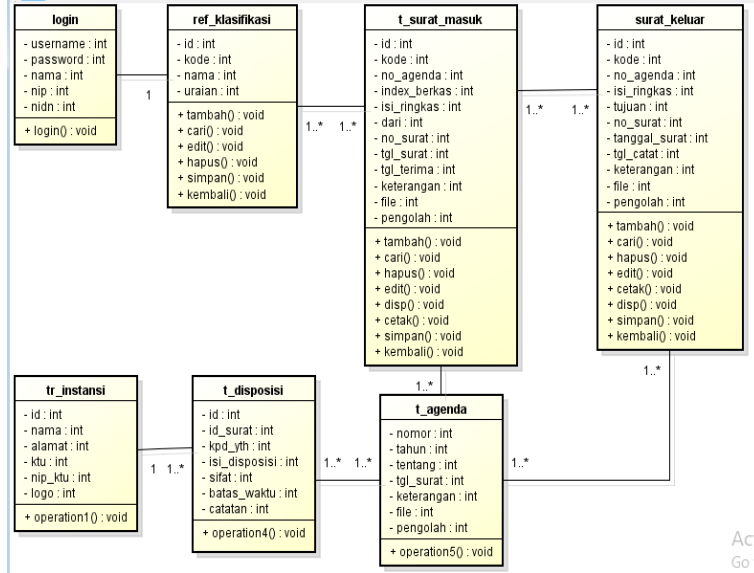

Gambar 5 Class Diagram

\section{Sequence Diagram}

Sequence diagram merupakan mengambarkan aktivitas kaprodi dan sekretaris didalam sebuah sistem yang dibangun agar proses jalannya sistem dapat dipahami oleh kaprodi dan sekretaris. Untuk lebih jelas perhatikan gambar berikut :

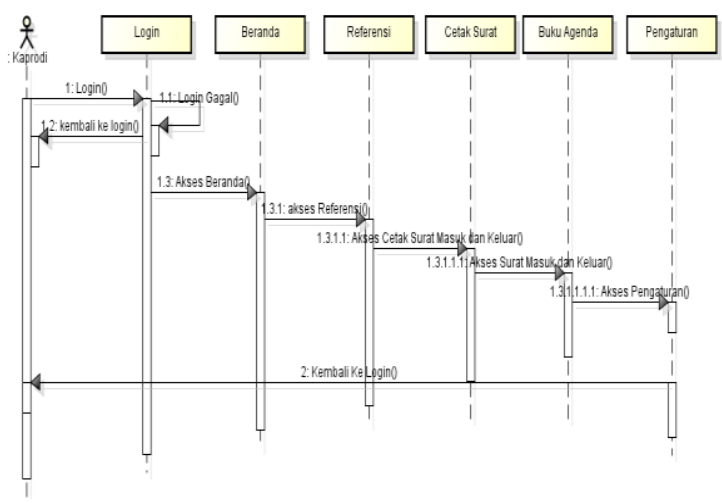

Gambar 6 Sequence Diagram Kaprodi

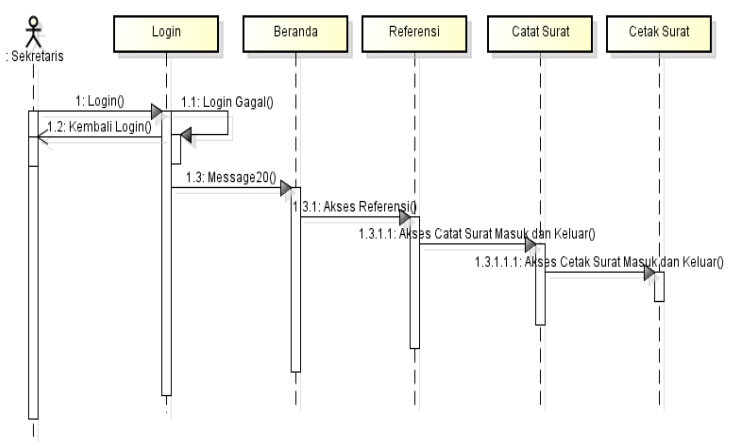

Gambar 7 Sequence Diagram Sekretaris

\section{Deployment Diagram}

Dari perancangan diagram akan dapat diketahui bagaimana menggambarkan processor pada diagram, Untuk lebih jelas perhatikan gambar berikut :

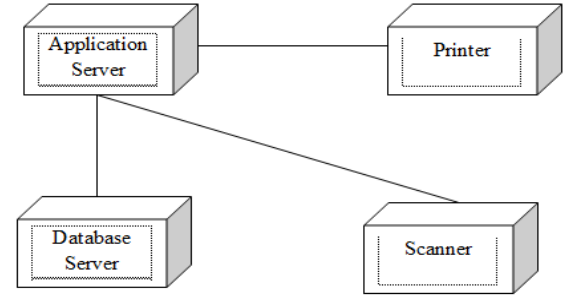

Gambar 8 Deployment Diagram

\section{Component Diagram}

Dari perancangan diagram akan dapat diketahui bagaimana menggambarkan modul perangkat lunak dengan antar muka, Untuk lebih jelas perhatikan gambar berikut :

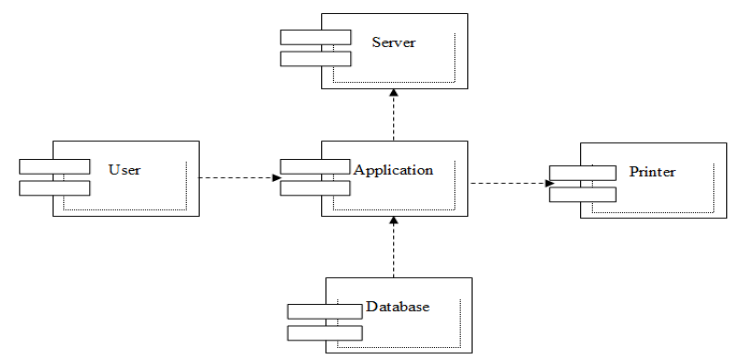

Gambar 9 Component Diagram

\section{Package Diagram}

Dari perancangan diagram akan dapat diketahui bagaimana menggambarkan sekelompok elemenelemen model, Untuk lebih jelas perhatikan gambar berikut :

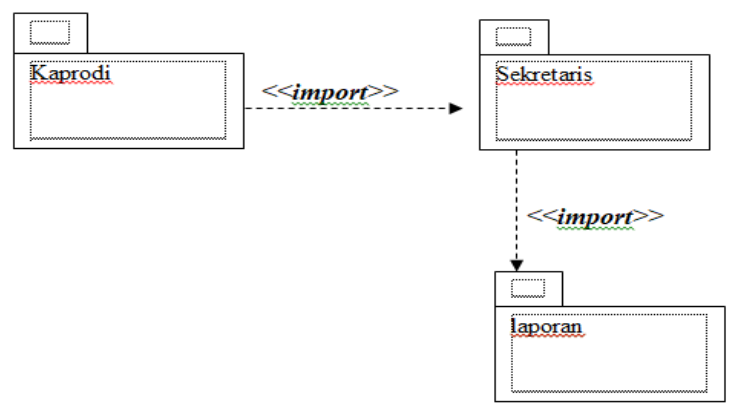

Gambar 10 Package Diagram

\section{Collaboration Diagram}

Dari perancangan diagram akan dapat diketahui bagaimana menggambarkan interaksi dari objek-objek yang menerima dan mengirim pesan, Untuk lebih jelas perhatikan gambar berikut : 


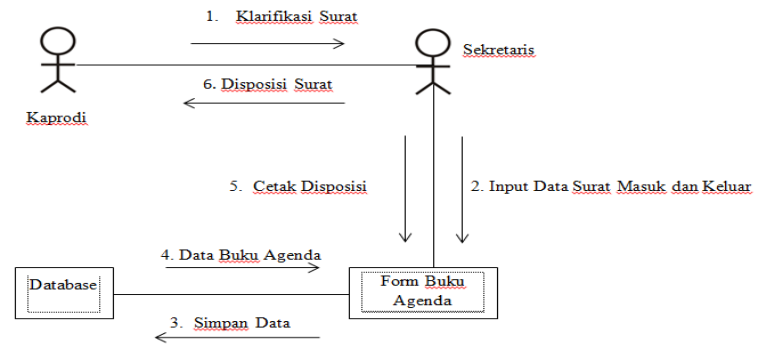

Gambar 11 Collaboration Diagram

\section{Implementasi}

Pada implementasi sistem ini menjelaskan penjabaran tentang sistem yang digunakan dalam pembuatan sistem arsip, adapun bentuk rancangannya adalah sebagai berikut :

1. Tampilan Menu Halaman Login

Halaman login adalah tampilan form untuk login oleh kaprodi dan sekretaris kedalam sistem arsip surat.

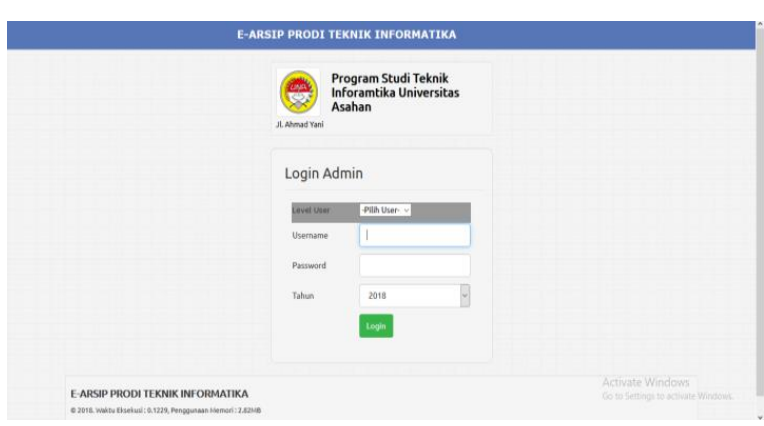

Gambar 12 Tampilan Menu Halaman Login

\section{Tampilan Halaman Utama Kaprodi}

Pada halaman ini merupakan halaman utama kaprodi. Pada halaman ini kaprodi dapat mengelola data arsip surat yang meliputi kelola referensi surat, cetak surat, buku agenda dan pengaturan lainnya.

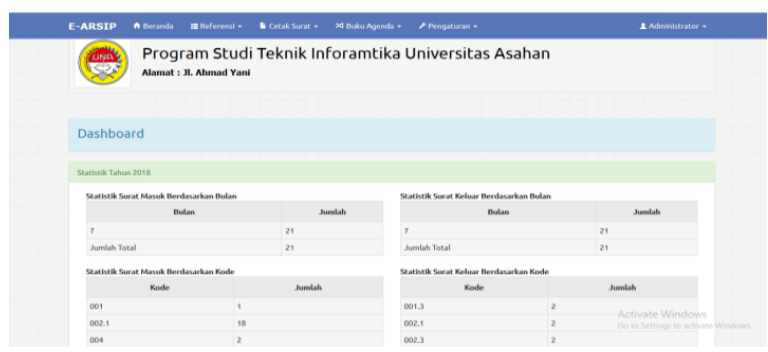

Gambar 13 Tampilan Halaman Utama Kaprodi

\section{Tampilan Menu Referensi Klasifikasi Surat}

Halaman ini berfungsi untuk mengatur nomor referensi surat yang ada pada fakultas.

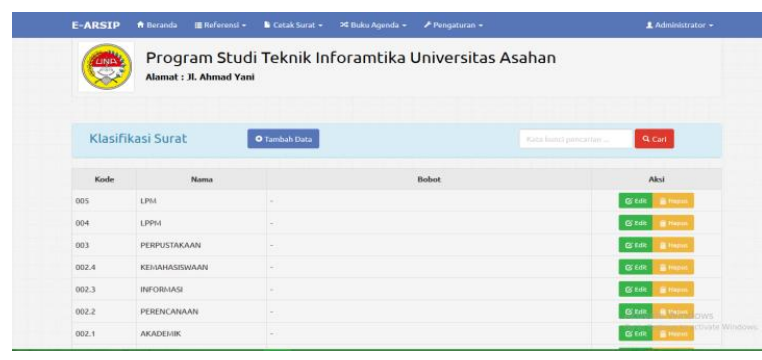

Gambar 14 Tampilan Menu Referensi Klasifikasi Surat

4. Tampilan Menu Cetak Surat Masuk dan Keluar

Halaman ini berfungsi untuk mencetak data buku agenda surat masuk yang dikirim dari tempat lain yang ditujukan ke program studi teknik informatika, Untuk detail perhatikan gambar berikut ini:

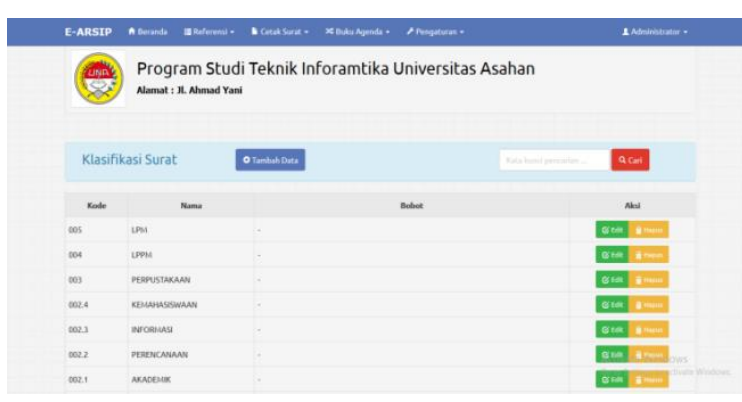

Gambar 15 Tampilan Menu Cetak Surat Masuk dan keluar

5. Tampilan Menu Buku Agenda Surat Masuk dan Surat Keluar

Halaman ini berfungsi untuk melihat data buku agenda surat masuk dan surat keluar yang telah diinputkan.

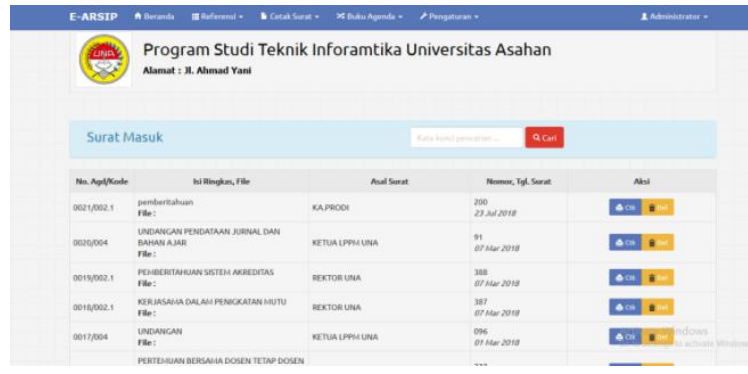

Gambar 16 Tampilan Menu Buku Agenda Surat Masuk dan Surat Keluar

6. Tampilan Menu Pengaturan Instansi Pengguna

Halaman pengaturan ini berfungsi untuk mengatur profil pengguna aplikasi arsip secara otomatis agar dapat melakukan perubahan. 


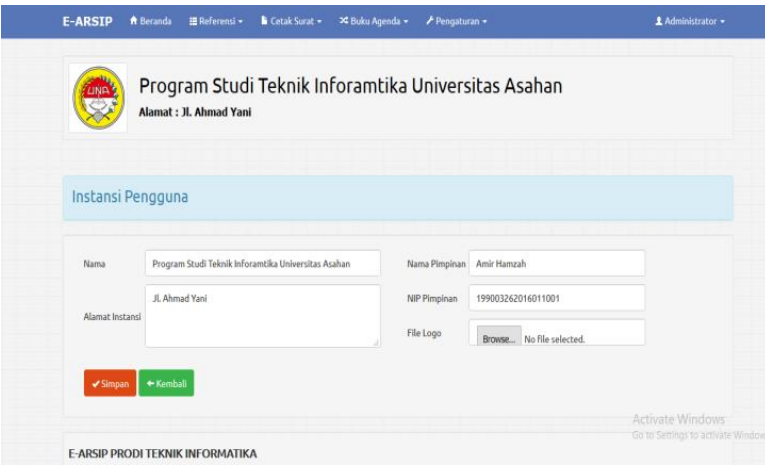

Gambar 17 Tampilan Menu Pengaturan Instansi Pengguna

7. Tampilan Menu Pengaturan Manajemen Akun Pada halaman ini berfungsi untuk mengatur akun username dan password admin dan juga user bagian umum. Untuk lebih detail perhatikan gambar berikut ini.

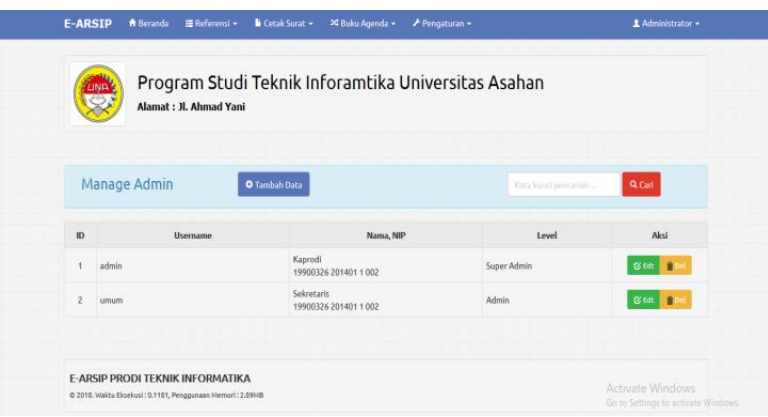

Gambar 18 Tampilan Menu Pengaturan Manajemen Akun

8. Tampilan Halaman Utama Sekretaris

Halaman ini merupakan halaman utama sekretaris untuk mengelola data surat masuk yang terdiri dari proses pencatatan surat dan buku agenda.

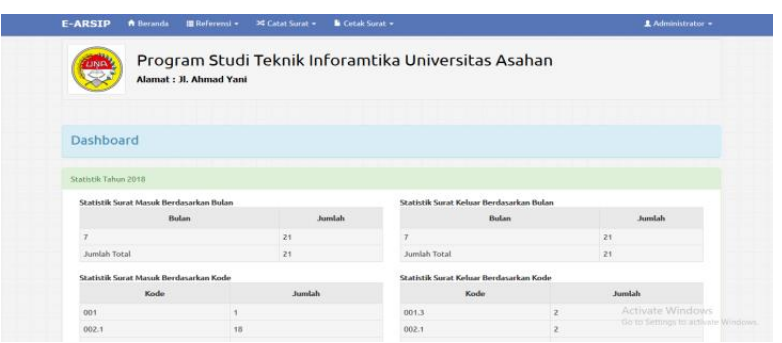

Gambar 19 Tampilan Halaman Utama Sekretaris

9. Tampilan Menu Referensi Klasisfikasi Surat

Pada halaman ini berfungsi untuk mengelola referensi penomoran surat yang ada pada program studi teknik informatika. Untuk lebih detail perhatikan gambar berikut.

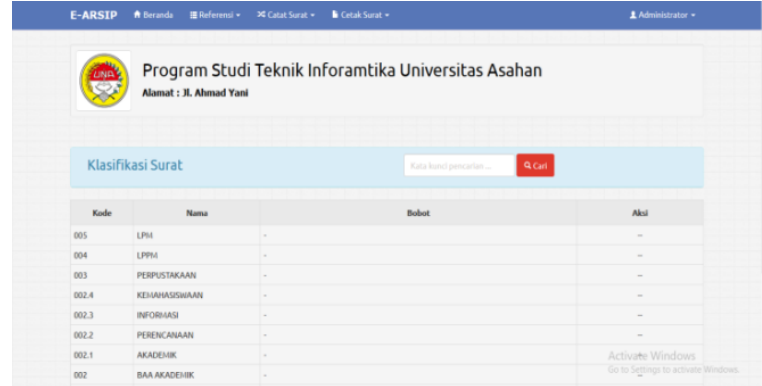

Gambar 20 Tampilan Menu Referensi Klasisfikasi Surat

10. Tampilan Menu Catat Surat Masuk

Halaman ini berfungsi untuk bagian sekretaris dalam proses mencatat surat masuk yang diterima oleh program studi teknik informatika.

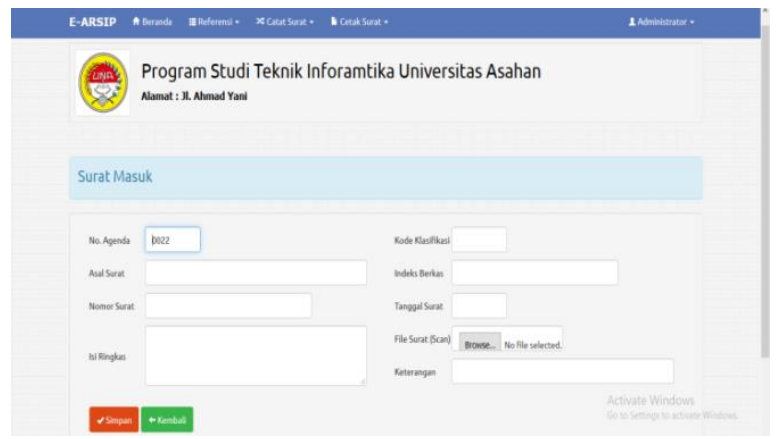

Gambar 21 Tampilan Menu Catat Surat Masuk

11. Tampilan Hasil Input Surat Masuk

Halaman ini berfungsi untuk bagian sekretaris untuk mengelola penginputan surat. Surat yang sudah di input dengan data yang sesuai maka akan dapat dilihat hasilnya pada halaman ini.

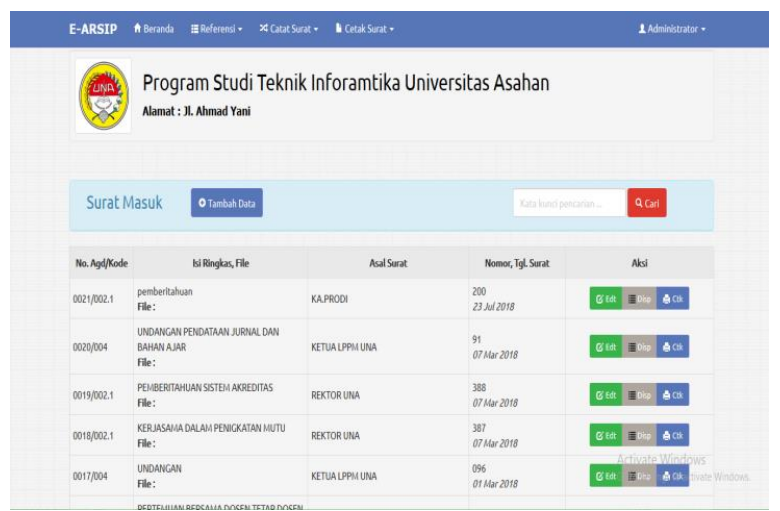

Gambar 22 Tampilan Hasil Input Surat Masuk

12. Tampilan Menu Catat Surat Keluar

Halaman ini berfungsi pada bagian sekretaris untuk mencatat surat keluar yang akan dikirim keluar dari fakultas. 


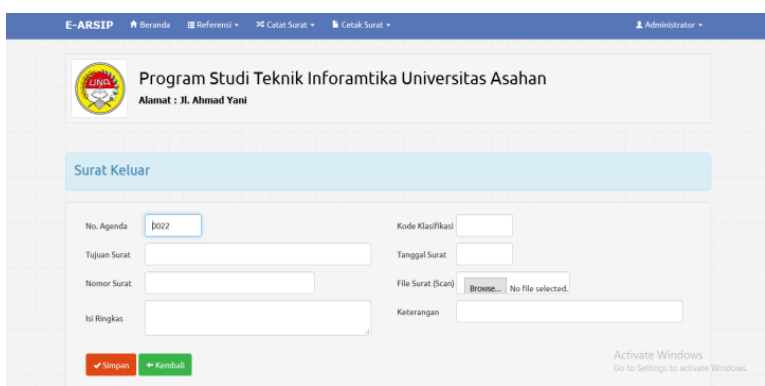

Gambar 23 Tampilan Menu Catat Surat Keluar

13. Tampilan Hasil Input Surat Keluar

Halaman ini berfungsi untuk melihat hasil inputan data surat keluar yang sebelumnya pernah di input oleh operator bagian umum dan hasilnya akan tampil pada halaman ini.

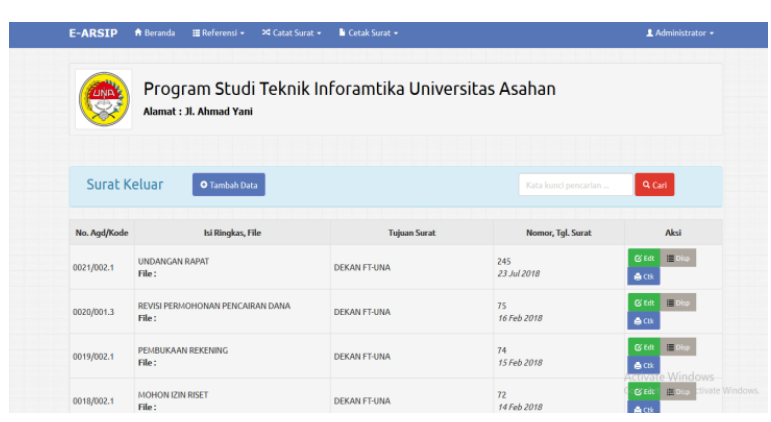

Gambar 24 Tampilan Hasil Input Surat Keluar

\section{V.PENUTUP}

\section{A. Kesimpulan}

Dari penjelasan yang telah diuraikan dapat ditarik kesimpulan mengenai hal-hal dasar yang sangat erat kaitannya dengan implementasi e-arsip, maka dapat disimpulkan sebagai berikut :

1. Aplikasi e-arsip memiliki fungsi scan yang kegunaan menginputkan scan surat yang ingin disimpan sehingga dapat menimalkan kehilangan dan rusaknya dokumen-dokumen penting.

2. Proses pencarian data dan informasi arsip pada program studi teknik informatika menjadi lebih mudah sehingga mudah ditemukan.

3. Aplikasi yang dihasilkan cukup akurat dan cukup valid, sehingga dapat membantu proses penyelenggara kearsipan yang sesuai dengan prinsip.

4. Aplikasi ini dikelola oleh kaprodi dan sekretaris.

\section{B. Saran}

Berdasarkan pembahasan yang telah peneliti lakukan, peneliti memberikan saran untuk dapat membantu proses pengolahan data arsip, yaitu sebagai berikut :

1. Diharapkan aplikasi ini tidak hanya digunakan pada Program Studi Teknik Informatika, tetapi juga digunakan pada Fakultas.

2. Untuk kedepannya aplikasi ini diharapkan bisa dikembangkankan sehingga penyelenggara kearsipan dapat dilaksanakan sesuai dengan prinsip, kaedah dan standar kearsipan.

\section{DAFTAR PUSTAKA}

[1] Ade Hendini. 2016. "Pemodelan Uml SistemInformasi Monitoring Penjualan Dan Stok Barang (Studi Kasus: Distro Zhezha Pontianak)'. Jurnal Khatulistiwa Informatika, Vol IV No 2. 107-116.

[2] Ajeng Puspitasari Rahastri. 2015. "Perancangan Dan Implementasi Sistem Informasi Sekolah (Studi Kasus Smp N 2 Patikraja Banyumas)”. Jurnal E-Proceeding Of Applied Science, Vol 1 No 3. 2660-2666, ISSN : 2442-5826.

[3] Angga Reza Palevi, Krisnawati. 2013. “Analisis Dan Perancangan Sistem Informasi Penerimaan Peserta Didik Baru Berbasis Website Pada Smp Negeri 2 Mojosongo Boyolali”. Jurnal Ilmiah DASI, Vol 14 No 04. 1-6, ISSN: 1411-3201.

[4] Cosmas Eko Suharyanto, Joni Eka Chandra, Fergyanto E Gunawan. 2017. "Perancangan Sistem Informasi PenggajianTerintegrasi Berbasis Web (Studi Kasus di Rumah Sakit St. Elisabeth)". Jurnal Teknologi dan Sistem Informasi, Vol 3 No 2. 225-232.

[5] Fauziah Latif, Aditya Wirangga Pratama. 2015. "Perancangan Sistem Informasi Manajemen Arsip Elektronik (E-Arsip) Berbasis Microsoft Access Pada PT. HI-TEST”. Jurnal Akuntansi, Ekonomi dan Manajemen Bisnis, Vol 3 No 1. 2131, ISSN: 2337-7887.

[6] Hasan Abdurahaman, Asep Ririh Riswaya. 2014. "Aplikasi Pinjaman Pembayaran Kredit Pada Bank Yudha Bhakti”. Jurnal Computech dan Bisnis, Vol 8 No 2. 61-69, ISSN: 2337-7887.

[7] Liza Yulianti dan Harry Aspriono. 2011. Website Unit Pelaksana Teknis Dinas (Uptd) Puskesmas Jembatan Kecil Kota Bengkulu Menggunakan Adobe Dreamweaver Cs3, Jurnal Media Infotama Vol. 7 No. 2. 
[8] Machsun Rifauddin. 2016. Pengelolaan Arsip Elektronik Berbasis Teknologi, Jurnal Khizanah Al-Hikmah, Vol. 4 No. 2.

[9] Medi Suhartanto. 2012. Pembuatan Website Sekolah Menengah Pertama Negeri 3 Delanggu Dengan Menggunakan Php Dan MySQL, Jurnal Speed - Sentra Penelitian Engineering dan Edukasi, Vol. 4 No. 1.

[10] Normah. 2017. Sistem Informasi Pengelolaan Administrasi Kearsipan Berbasis Teknologi Informasi dan Komunikasi dengan Efiling System, jurnal sistem informasi STMIK antar bangsa, Vol. VI No.1.

[11] Rani Kurniasari. 2013. Sistem Pengelolaan Arsip Elektronik Serta Dampaknya Terhadap Efektifitas Penyimpanan Dan Penemuan Kembali Arsip, jurnal Widya Cipta, Vol. V No. 1.

[12] Rita Prima Bendriyanti dan Leni Natalia Zulita. 2012. Implementasi E-Arsip Pada Kanwil Kementerian Agama Provinsi Bengkulu, Jurnal Media Infotama, Vol. 8 No.1.

[13] Sri Haryanti dan Tri Irianto. 2011. Rancang Bangun Sistem Informasi E- Commerce Untuk Usaha Fashion Studi Kasus Omah Mode Kudus, Jurnal Speed - Sentra Penelitian Engineering dan Edukasi, Vol. 3 No. 1.

[14] Tim Madcoms. (2016). Pemprograman PHP dan MySQL Untuk Pemula. Edisi Pertama. Yogyakarta : Andi Offset. 